
RESEARCH AND DEVELOPMENT

\author{
http://journal.unnes.ac.id/sju/index.php/higeia
}

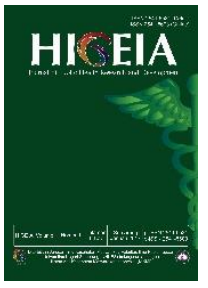

\title{
KEMAMPUAN EKSTRAK BUAH PARE TERHADAP KEMATIAN NYAMUK Aedes aegypti
}

\section{Gita Dheasabel ${ }^{\bowtie}$, Muhammad Azinar}

Epidemiologi dan Biostatistika, Jurusan Ilmu Kesehatan Masyarakat, Fakultas Ilmu Keolahragaan, Universitas Negeri Semarang

\section{Info Artikel}

Sejarah Artikel:

Diterima Februari 2018

Disetujui Maret 2018

Dipublikasikan April

2018

\section{Keywords:}

Aedes aegypti, insecticide,

bitter melon

\begin{abstract}
Abstrak
Nyamuk Aedes aegypti merupakan vektor pembawa virus dengue yang dapat menularkan penyakit DBD dengan angka kesakitan mencapai 50,75/100.000 penduduk tahun 2015. Usaha untuk mengurangi dampak negatif insektisida kimia dapat dilakukan dengan pengendalian alternative dengan menggunakan insektisida nabati. Penelitian ini dilakukan pada tahun 2017. Tujuan penelitian ini adalah untuk menganalisis daya bunuh ekstrak buah pare terhadap nyamuk Aedes aegypti. Jenis penelitian ini adalah eksperimen murni dengan desain post test only control group design dengan lima varian konsentrasi ekstrak sebesar 13\%, 19\%, 27\%, 40\%, dan 59\% dengan lima kali pengulangan. Hasil uji kruskal wallis menunjukkan adanya perbedaan rata-rata jumlah kematian nyamuk Aedes aegypti pada berbagai konsentrasi ekstrak buah pare, ditunjukkan dengan nilai signifikansi $\mathrm{p}=0,001(\mathrm{p}<0,05)$. Analisis probit didapatkan $\mathrm{LC}_{50}$ pada konsentrasi $24,41 \%$ dan $\mathrm{LC}_{90}$ pada konsentrasi $70,54 \%$. Simpulan penelitian ini yaitu ekstrak buah pare memiliki efek insektisida terhadap nyamuk Aedes aegypti.
\end{abstract}

\begin{abstract}
The mosquito of Aedes aegypti was the vector of the dengue virus could transmit the disease through bites DBD with incidence rate of 50,75/100.000 population in 2015. The efforts to reduce the negative impact of chemical insecticides could be controlled with an insecticides plant. This study was condiucted in 2017. This control could be done by using materials that came from plant, one of them namely bitter melon (Momordica charantia L). The purpose of this research was to analyze the kill power of bitter melon extracts against the mosquito of Aedes aegypti. This type of research was pure experiment with the design of the post test only control group design with five variants of extract concentration of $13 \%, 19 \%, 27 \%, 40 \%$, and $59 \%$ with five repetitions. A kruskal wallis test result showed a difference in the average number of deaths the mosquito of Aedes agypti in various concentration of bitter melon extract, indicated by the value of significance $p=0,001$ $(p<0,05)$. The probit analysis obtained $L C_{50}$ at $24,41 \%$ concentration and $L C_{90}$ at $70,54 \%$ concentratin. The summary of this research, namely bitter melon extracts has the effect of insecticide against the mosquito of Aedes aegypti.
\end{abstract}

E-mail: gitadheasabe195@gmail.com 


\section{PENDAHULUAN}

Nyamuk Aedes aegypti merupakan jenis nyamuk dari genus Aedes yang dapat menularkan penyakit melalui gigitan nyamuk tersebut. Penyakit yang ditularkan oleh vektor nyamuk Aedes aegypti salah satunya yaitu demam berdarah dengue (DBD). Penyakit DBD yaitu penyakit yang disebabkan virus dengue yang tergolong dalam arthropod-bone virus, genus flavivirus, dan famili flaviviridae. Nyamuk Aedes aegypti merupakan vektor utama penyebar virus dengue. Spesies lain seperti Aedes albopictus, Aedes polynesisensis, dan Aedes scutellaris dianggap sebagai vektor sekunder. Penyakit DBD dapat muncul setiap tahun dan dapat menyerang seluruh kelompok umur (Kementrian Kesehatan RI, 2016; Suwandi, 2017).

Penyakit DBD di Indonesia mengalami peningkatan selama tiga tahun berturut-turut dari tahun 2011 sampai 2013. Tahun 2011 jumlah kasus penderita penyakit DBD sebanyak 65.725 dengan angka kesakitan/inciden rate sebanyak 27,67 per 100.000 penduduk. Tahun 2012 mengalami peningkatan menjadi 90.245 kasus dengan IR 37,27 per 100.000 penduduk, mengalami peningkatan lagi pada tahun 2013 sebanyak 112.511 kasus dengan IR 45,85 per 100.000 penduduk. Tahun 2014 terjadi penurunan menjadi 100.347 kasus dengan IR 39,8 per 100.000 penduduk dengan angka kematian/case fatality rate $0,9 \%$. Tahun 2015 terjadi peningkatan kasus menjadi 129.650, dilaporkan angka kesakitan/inciden rate sebesar 50,75 per 100.000 penduduk dan angka kematian/case fatality rate sebesar $0,83 \%$ (Kementrian Kesehatan RI, 2016). Persebaran virus apabila tidak segera dilakukan penanganan akan dapat mengakibatkan kematian dan menimbulkan dampak sosial maupun ekonomi.

Strategi untuk memutus rantai penyakit dalam mengurangi jumlah angka kesakitan dan angka kematian DBD yaitu dapat dilakukan dengan pengendalian vektor penyakit. Upaya pengendalian nyamuk yang telah dilakukan antara lain dengan cara pengendalian lingkungan, pengendalian biologi, pengendalian kimia, dan pengendalian fisik. Pengendalian lingkungan merupakan cara yang paling efektif dan efisien yang membutuhkan partisipasi masyarakat, namun kesadaran masyarakat di Indonesia masih tergolong rendah. Pengendalian menggunakan agen biologi di alam cukup banyak, namun hanya beberapa saja yang dapat digunakan, sedangkan pengendalian vektor secara fisik membutuhkan biaya yang mahal (Trapsilowati, 2015; Kementrian Kesehatan RI, 2010). Pengendalian vektor secara kimia adalah cara yang paling popular digunakan di masyarakat (Kementrian Kesehatan RI, 2010). Penggunaan insektisida kimia sintetik memiliki kelebihan yaitu praktis mengaplikasiannya, hasil cepat terlihat, dan tersedia dalam jumlah banyak namun jika digunakan secara terus menerus dapat menimbulkan masalah, diantaranya menyebabkan pencemaran lingkungan karena residu tidak mudah terurai, matinya organisme bukan sasaran, dan menyebabkan resistensi pada serangga sasaran (Kristina dalam Panghiyangani, 2012).

Beberapa penelitian telah membuktikan resistensi pada serangga sasaran terhadap insektisida. Penelitian yang dilakukan oleh Prasetyowati (2016) menyatakan bahwa nyamuk Aedes aegypti di Jakarta Timur, Jakarta Barat, dan Jakarta Selatan telah resisten terhadap insektisida golongan organofosfat. Penelitian lain yang dilakukan oleh Ikawati (2015) menyatakan bahwa nyamuk Aedes aegypti di 9 kabupaten pada lokasi penelitian di Jawa Tengah telah resisten terhadap insektisida malathion, 8 kabupaten resisten terhadap cypermethrin.

Usaha untuk mengurangi dampak negatif dari penggunaan insektisida kimia sintetik dapat dilakukan dengan pengendalian yang bersifat alami (Kristina dalam Panghiyangani, 2012). Pengendalian alami dapat menggunakan bioinsektisida atau insektisida nabati yang merupakan insektisida berbahan dasar tumbuhan yang mengandung zat yang bersifat toksik terhadap serangga. Pemanfaatan bahan tumbuhan sebagai insektisida nabati semakin meningkat sebagai upaya kembali ke alam 
(Wiryadiputra, 2014). Keunggulan menggunakan insektisida nabati hanya membunuh organisme sasaran, tapi tidak menimbulkan pencemaran lingkungan karena residunya cepat terurai oleh alam (Wulandari, 2012).

Tanaman pare merupakan tanaman yang tumbuh di daerah beriklim tropis dengan rentan ketinggian 0-1.500 mdpl (Astriani, 2016). Tanaman yang memiliki nama latin Momordica charantia $\mathrm{L}$ ini mudah didapat karena tersebar luas di Indonesia serta dapat tumbuh dengan baik. Biasanya oleh masyarakat buah pare digunakan sebagai sayur, selain itu digunakan masyarakat sebagai obat penurun panas dan menormalkan siklus menstruasi (Borokini, 2013).

Tanaman pare mengandung senyawa metabolit alkaloid dan flavonoid yang terdapat dalam buahnya (Syam, 2015). Buah pare merupakan salah satu bagain dari tanaman pare yang diduga dapat digunakan sebagai insektisida. Senyawa metabolit akoloid, dan flavonoid yang terdapat dalam tumbuhan dapat digunakan sebagai insektisida. Penelitian Syam (2015) menyatakan bahwa buah pare mengandung senyawa aktif alkaloid dan flavonoid. Kandungan senyawa aktif yang terdapat dalam ekstrak buah pare terbukti efektif dapat digunakan sebagai larvasida Aedes aegypti (Susilawati, 2015; Syam, 2015). Penelitian mengenai efek insektisida terhadap larva Aedes aegypti sudah pernah dilakukan, dari penelitianpenelitian tersebut terbukti bahwa buah pare (Momordica charantia L) berpotensi sebagai bahan pengendalian vektor, maka peneliti merasa perlu dilakukan penelitian mengenai efek insektisida ekstrak buah pare (Momordica charantia L) terhadap nyamuk Aedes aegypti.

Obat nyamuk elektrik cair merupakan salah satu alternatif pengendalian vektor yang memiliki beberapa kelebihan dibanding dengan cara yang lain. Diantaranya yaitu praktis, tidak meninggalkan asap, tidak meninggalkan abu, apabila habis dapat diisi ulang, serta cepat ternetralisir oleh lingkungan (Nikmah, 2016).

Mengingat masih tingginya laju pertumbuhan nyamuk Aedes aegypti yang menyebabkan penyakit demam berdarah dengue di Indonesia, memberi inspirasi penulis untuk meneliti lebih lanjut masalah tersebut. Tujuan penelitian ini adalah untuk menguji kemampuan ekstrak buah pare (Momordica charantia L) terhadap kematian nyamuk Aedes aegypti dengan metode elektrik cair.

\section{METODE}

Jenis penelitian yang digunakan adalah eksperimen murni (true experiment) dengan desain penelitian yang digunakan yaitu Posttest only control group design. Perlakuan menggunakan ekstrak buah pare (Momordica charantia L) hanya diberi pada kelompok eksperimen, sedangkan pada kelompok kontrol negatif hanya diberi perlakuan dengan menggunakan akuades dan untuk kelompok kontrol positif menggunakan obat nyamuk yang berbahan aktif transflutrin. Pengukuran pada ketiga kelompok sampel tidak dilakukan pada awal perlakuan, tetapi dilakukan 24 jam setelah perlakuan dengan menghitung jumlah nyamuk yang mati.

Sumber data dalam penelitian ini yaitu menggunakan data primer. Data primer yaitu data yang diperoleh atau dikumpulkan sendiri oleh peneliti dari objek yang diteliti selama penelitian. Dalam penelitian ini data primer diperoleh langsung melalui lembar observasi pada penelitian eksperimen. Data primer dalam penelitian ini adalah jumlah kematian nyamuk Aedes aegypti dalam setiap konsentrasi.

Sampel dalam penelitian ini yaitu nyamuk Aedes aegypti betina berumur 2-5 hari yang diambil secara random sampling dari populasi nyamuk Aedes aegypti. Pengambilan nyamuk dilakukan dengan menggunakan aspirator kemudian dimasukkan ke dalam paper cup. Jumlah sampel nyamuk yang digunakan dalam penelitian ini sebanyak 20 nyamuk Aedes aegypti per kelompok, untuk tiap kelompok dilakukan pengulangan 5 kali. Kelompok perlakuan dibagi menjadi 7 kelompok, 2 kelompok kontrol, dan 5 kelompok perlakuan, sehingga seluruh nyamuk yang dibutuhkan yaitu 700 nyamuk. 
Buah pare (Momordica charantia L) yang digunakan dalam penelitian diperoleh dari Pasar Kliwon, Kecamatan Temanggung, Kabupaten Temanggung. Buah pare yang digunakan untuk pembuatan ekstrak pada penelitian dipilih dengan kondisi yang masih segar dan berwarna hijau tua. Pembelian buah pare dilakukan pada pagi hari karena untuk mendapatkan buah pare yang masih segar. Setelah itu buah pare (Momordica charantia L) diproses menjadi ekstrak dengan metode maserasi di Laboratorium Biologi Fakultas Matematika dan Ilmu Pengetahuan Alam Universitas Negeri Semarang (FMIPA UNNES).

Pengujian insektisida ekstrak buah pare (Momordica charantia L) diilakukan dengan menggunakan alat elektrik cair yang beredar di masyarakat. Penghantar cairan insektisida ekstrak buah pare (Momordica charantia L) yang akan diuapkan pada obat nyamuk diganti dengan menggunakan kapas. Penghantar diganti menggunakan kapas dalam penelitian karena penghantar tersebut dimungkinkan masih mengandung insektisida kimia yang terserap, sehingga dapat mempengaruhi besarnya kematian nyamuk Aedes aegypti.

Penelitian obat nyamuk elektrik cair berinsektisida buah pare untuk membunuh nyamuk Aedes aegypti dilaksanakan di Laboratorium Entomologi Balai Litbang P2B2 Banjarnegara. Penelitian dilaksanakan pada tanggal 12-20 Desember 2017.

Alat dan bahan untuk pembuatan ekstrak buah pare: buah pare, ethanol $70 \%$, pisau, blender, kertas saring, rotary evaporator dan oven. Sedsangkan, alat dan bahan untuk pengujian: alat elektrik cair, ekstrak buah pare, akuades, obat nyamuk berbahan transflutrin, glass chamber, stop watch, thermohygrometer, paper cup, kain kasa, karet gelang, air gula, kapas, aspirator, alat tulis dan lembar observasi.

Cara pembuatan ekstrak buah pare yaitu Buah pare mentah dibersihkan kemudian dicuci kemudian dipotong kecil-kecil, Buah pare dikeringkan dengan cara diangin-anginkan untuk menghilangkan kadar air, Selanjutnya buah pare dihaluskan hingga menjadi serbuk, Serbuk buah pare dimaserasi dengan etanol $70 \%$ selama 24 jam sambil diaduk-aduk secara berkala, kemudian disaring, Ampas sisa dimaserasi lagi 3 kali supaya semua zat yang terkandung dalam buah pare tersebut terekstrak, Semua filtrat selanjutnya dikumpulkan dan di evaporasi dengan pelarut etanol $70 \%$ dengan suhu $60^{\circ} \mathrm{C}$ hingga didapat ekstrak buah pare.

Perlakuan pemberian obat nyamuk elektrik cair berinsektisida ekstrak buah pare (Momordica charantia L) dimulai dengan melakukan persiapan nyamuk yaitu memasukkan 20 nyamuk Aedes aegypti ke dalam papercup. Penelitian yang akan dilakukan membutuhkan 35 papercup. Kemudian mempersiapkan ekstrak buah pare yang sudah diencerkan dengan akuades dengan konsentrasi $13 \%, 19 \%, 27 \%, 40 \%$ dan $59 \%$.

Cara pengujiannya yaitu glass chamber dibersihkan menggunakan air detergen kemudian dibilas dengan air dan dikeringkan dengan menggunakan lap, obat nyamuk elektrik dengan ekstrak buah pare dipanaskan dalam draft room selama 4 jam, setelah itu dipindahkan ke dalam glass chamber selama 3 menit dan tutup ventilasi, Obat nyamuk elektrik cair dikeluarkan dan dipindahkan dari glass chamber ke dalam draft room (obat nyamuk tetap dipanaskan selama pengujian), kemudian 20 nyamuk yang akan diuji dilepas ke dalam glass chamber. Memanaskan obat nyamuk uap cair elektrik di dalam draft room selama 4 jam, Mencatat jumlah nyamuk yang mati pada detik ke 30 , lalu menit ke - $1,2,3,4,5,6,7,8,9,10,15,20$, di setiap periode waktu di lembar pengamatan, Selanjutnya semua nyamuk dipindahkan menggunakan aspirator ke dalam paper cup yang telah diberi kapas yang dibasahi air gula, kemudian disimpan / holding selama 24 jam. Selama holding disediakan air gula untuk kebutuhan makan nyamuk, Pengujian selanjutnya dengan konsentrasi yang berbeda yang diambil dari botol yang belum terpakai untuk uji sebelumnya, sebelum melakukan pengujian selanjutnya, glass chamber dibersihkan dengan lap dan sabun pembersih kemudian dilap dengan air dan dikeringkan dengan lap kering, mencatat temperatur serta kelembaban ruangan. 
Pembuagan limbah nyamuk usai penelitian dengan cara nyamuk hasil pengujian yang masih hidup dikumpulkan dalam kandang nyamuk, mematikan nyamuk yang masih hidup dengan cara membasahi handuk menggunakan air kemudian dikibas-kibaskan ke dalam kandang nyamuk, kemudian semua nyamuk yang telah mati setelah penelitian dikumpulkan dan dibakar.

Teknik pengumpulan data dilakukan dengan cara (1) Editing, yaitu melakukan pengecekan kelengkapan data pengisian dari lembar observasi mengenai kematian nyamuk Aedes aegypti; (2) Coding, yaitu merubah angka berbentuk huruf menjadi data berbentuk bilangan dan mengklasifikasikan data hasil pengamatan menurut kategori masing-masing; (3) Processing, yaitu memasukkan data atau entry data ke program computer; (4) Cleaning, yaitu melakukan pengecekan data yang sudah dimasukkan.

Data hasil penelitian yang diperoleh kemudian dianalisis secara statistic menggunakan uji probit, uji normalitas data dengan menggunakan Saphiro Wilk, uji homogenitas varians dengan uji levene, kemudian uji Kruskal Wallis dilanjutkan dengan analisis Post Hoc.

\section{HASIL DAN PEMBAHASAN}

Suhu dalam penelitian dilakukan pengukuran dengan menggunakan alat thermohygrometer untuk menjaga kestabilan suhu udara, sehingga tidak mempengaruhi hasil penelitian. Pengukuran suhu dilakukan sebelum pengujian dan setelah pengujian pada masingmasing kelompok pengujian. Adapaun hasil pengukuran suhu penelitian awal pengujian dan akhir pengujian pada penelitian selama 24 jam dapat dilihat pada Tabel 1.

Hasil pengukuran suhu pada penelitian berkisar antara $\pm 25-28^{\circ} \mathrm{C}$. Hal tersebut dapat dikatakan bahwa suhu dalam penelitian stabil. Suhu pada penelitian yang dilakukan memenuhi standar untuk pengujian nyamuk yaitu berkisar 25-29 ${ }^{\circ} \mathrm{C}$ (Nihayah, 2014). Jadi dapat disimpulkan bahwa dalam penelitian ini kematian nyamuk Aedes aegypti tidak disebabkan oleh suhu lingkungan pada penelitian.

Pengukuran kelembaban pada penelitian dilakukan untuk menjaga kestabilan uap air di udara, sehingga nyamuk dapat berkembang sesuai siklus hidupnya. Pengukuran dilakukan menggunakan alat thermohygrometer. Pengukuran kelembaban dilakukan sebelum pengujian dan setelah pengujian pada masingmasing kelompok pengujian. Adapaun hasil pengukuran kelembaban sebelum pengujian dan setlah pengujian pada penelitian selama 24 jam dapat dilihat pada Tabel 2. Hasil pengukuran kelembaban pada penelitian ini yaitu berkisar antara $\pm 72-74 \%$.

Hal tersebut menunjukkan bahwa kelembaban dalam penelitian stabil dan memenuhi standar untuk pengujian nyamuk yaitu berkisar antara 72-80\% (Nihayah, 2014). Hal tersebut menunjukkan bahwa adanya kematian nyamuk tidak disebabkan oleh kelembaban lingkungan pada penelitian.

Tabel 1. Hasil Pengukuran Suhu

\begin{tabular}{ccccccccccc}
\hline $\begin{array}{c}\text { Konsentra- } \\
\text { si Ekstrak } \\
\text { Buah Pare }\end{array}$ & $\begin{array}{c}\text { Awal } \\
\left({ }^{\circ} \mathrm{C}\right)\end{array}$ & $\begin{array}{c}\text { Akhir } \\
\left({ }^{\circ} \mathrm{C}\right)\end{array}$ & $\begin{array}{c}\text { Awal } \\
\left({ }^{\circ} \mathrm{C}\right)\end{array}$ & $\begin{array}{c}\text { Akhir } \\
\left({ }^{\circ} \mathrm{C}\right)\end{array}$ & $\begin{array}{c}\text { Awal } \\
\left({ }^{\circ} \mathrm{C}\right)\end{array}$ & $\begin{array}{c}\text { Akhir } \\
\left({ }^{\circ} \mathrm{C}\right)\end{array}$ & $\begin{array}{c}\text { Awal } \\
\left({ }^{\circ} \mathrm{C}\right)\end{array}$ & $\begin{array}{c}\text { Akhir } \\
\left({ }^{\circ} \mathrm{C}\right)\end{array}$ & $\begin{array}{c}\text { Awal } \\
\left({ }^{\circ} \mathrm{C}\right)\end{array}$ & $\begin{array}{c}\text { Akhir } \\
\left({ }^{\circ} \mathrm{C}\right)\end{array}$ \\
\hline $13 \%$ & 25,6 & 25,6 & 25,7 & 25,7 & 27,0 & 27,0 & 27,2 & 27,2 & 27,2 & 27,2 \\
$19 \%$ & 27,6 & 27,6 & 27,6 & 27,8 & 27,8 & 27,8 & 28,2 & 28,2 & 28,2 & 28,3 \\
$27 \%$ & 27,5 & 27,5 & 27,5 & 27,5 & 27,6 & 27,7 & 27,7 & 27,7 & 28,1 & 28,1 \\
$40 \%$ & 26,7 & 26,7 & 26,7 & 26,8 & 27,1 & 27,1 & 27,1 & 27,2 & 28,1 & 28,1 \\
$59 \%$ & 27,2 & 27,2 & 27,2 & 27,2 & 28,2 & 28,2 & 28,2 & 28,3 & 28,3 & 28,3 \\
Akuades & 26,8 & 26,8 & 26,8 & 26,8 & 27,1 & 27,1 & 27,2 & 27,2 & 27,2 & 27,2 \\
$\begin{array}{c}\text { Obat nya- } \\
\text { muk ber- } \\
\text { bahan }\end{array}$ & 27,6 & 27,6 & 27,6 & 27,6 & 27,8 & 27,8 & 26,8 & 26,8 & 26,8 & 26,8 \\
transflutrin & & & & & & & & & & \\
\hline
\end{tabular}


Tabel 2. Hasil Pengukuran Kelembaban

\begin{tabular}{ccccccccccc}
\hline $\begin{array}{c}\text { Konsentrasi } \\
\text { Ekstrak }\end{array}$ & \multicolumn{2}{c}{ Replikasi I } & \multicolumn{2}{c}{ Replikasi II } & \multicolumn{2}{c}{ Replikasi III } & \multicolumn{2}{c}{ Replikasi IV } & \multicolumn{2}{c}{ Replikasi V } \\
Buah Pare & $\begin{array}{c}\text { Awal } \\
(\%)\end{array}$ & $\begin{array}{c}\text { Akhir } \\
(\%)\end{array}$ & $\begin{array}{c}\text { Awal } \\
(\%)\end{array}$ & $\begin{array}{c}\text { Akhir } \\
(\%)\end{array}$ & $\begin{array}{c}\text { Awal } \\
(\%)\end{array}$ & $\begin{array}{c}\text { Akhir } \\
(\%)\end{array}$ & $\begin{array}{c}\text { Awal } \\
(\%)\end{array}$ & $\begin{array}{c}\text { Akhir } \\
(\%)\end{array}$ & $\begin{array}{c}\text { Awal } \\
(\%)\end{array}$ & $\begin{array}{c}\text { Akhir } \\
(\%)\end{array}$ \\
\hline $13 \%$ & 72 & 72 & 72 & 72 & 73 & 73 & 73 & 73 & 73 & 73 \\
$19 \%$ & 72 & 73 & 73 & 73 & 73 & 73 & 72 & 72 & 72 & 72 \\
$27 \%$ & 72 & 72 & 73 & 73 & 73 & 73 & 72 & 72 & 73 & 74 \\
$40 \%$ & 74 & 74 & 74 & 74 & 74 & 74 & 73 & 73 & 73 & 73 \\
$59 \%$ & 73 & 72 & 72 & 72 & 72 & 73 & 73 & 73 & 73 & 73 \\
Air & 72 & 72 & 72 & 72 & 72 & 72 & 73 & 74 & 74 & 74 \\
$\begin{array}{c}\text { Obat nya- } \\
\text { muk berba- } \\
\text { han aktif }\end{array}$ & 72 & 72 & 72 & 73 & 73 & 73 & 73 & 73 & 73 & 73 \\
transflutrin & & & & & & & & & & \\
\hline
\end{tabular}

Umur nyamuk Aedes aegypti pada penlitian yang dilakukan dikendalikan dengan menggunakan nyamuk Aedes aegypti umur 2-5 hari. Umur tersebut merupakan umur nyamuk dengan daya tahan tubuh yang baik, nyamuk masih kuat, dan sudah produktif. Nyamuk dengan umur kurang dari 2 hari memiliki fisik yang masih lemah sehingga lebih mudah mati. Umur nyamuk lebih dari 5 hari memiliki keadaan fisik yang dengan ketahanan tubuh yang mulai menurun dan dapat meningkatkan risiko kematian (Nikmah, 2016).

Pengujian insektisida ekstrak buah pare (Momordica charantia L) diilakukan dengan menggunakan alat elektrik cair yang beredar di masyarakat. Penghantar cairan insektisida ekstrak buah pare (Momordica charantia L) yang akan diuapkan pada obat nyamuk diganti dengan menggunakan kapas. Penghantar diganti menggunakan kapas dalam penelitian karena penghantar tersebut dimungkinkan masih mengandung insektisida kimia yang terserap, sehingga dapat mempengaruhi besarnya kematian nyamuk Aedes aegypti. Adapaun hasil pengamatan kematian nyamuk Aedes aegypti pada penelitian selama 24 jam dapat dilihat pada Tabel 3.

Hasil pengamatan pada penelitian yang dilakukan selama 24 jam di Balai Litbang P2B2 Banjarnegara didapatkan hasil rata-rata \% kematian nyamuk Aedes aegypti pada konsentrasi $13 \%$ adalah sebesar $27 \%$, pada konsentrasi $19 \%$ adalah sebesar 33\%, pada konsentrasi $27 \%$ adalah sebesar $54 \%$, pada konsentrasi $40 \%$ adalah sebesar $74 \%$, pada konsentrasi $59 \%$ adalah sebesar $86 \%$, pada kontrol negatif sebesar $0 \%$, dan pada kontrol positif sebesar $100 \%$. Hal tersebut menunjukkan bahwa obat nyamuk elektrik cair berbahan ekstrak buah pare (Momordica charantia L) dapat membunuh nyamuk Aedes aegypti, semakin tinggi konsentrasi ekstrak buah pare (Momordica charantia L) maka semakin banyak nyamuk Aedes aegypti yang mati. Hal ini dikarenakan semakin tinggi ekstrak buah pare (Momordica charantia $\mathrm{L}$ ), semakin besar pula zat aktif yang

Tabel 3. Hasil Pengamatan Kematian Nyamuk Aedes aegypti Setelah Kontak dengan Ekstrak Buah Pare selama $24 \mathrm{Jam}$

\begin{tabular}{lcccccc}
\hline \multirow{2}{*}{ Kelompok } & \multicolumn{5}{c}{ Ulangan } & Rata-rata \\
\cline { 2 - 6 } & I & II & III & IV & V & \\
\hline I (konsentrasi 13\%) & 3 & 5 & 5 & 6 & 7 & $5,2(26 \%)$ \\
II (konsentrasi 19\%) & 7 & 6 & 8 & 5 & 7 & $6,6(33 \%)$ \\
III (konsentrasi 27\%) & 15 & 16 & 15 & 13 & 15 & $10,8(54 \%)$ \\
IV (konsentrasi 40\%) & 15 & 16 & 15 & 13 & 15 & $14,8(74 \%)$ \\
V (konsentrasi 59\%) & 18 & 17 & 16 & 17 & 18 & $17,2(86 \%)$ \\
Akuades & 0 & 0 & 0 & 0 & 0 & $0(0 \%)$ \\
Obat nyamuk berbahan & 20 & 20 & 20 & 20 & 20 & $20(100 \%)$ \\
aktif transflutrin & & & & & & \\
\hline
\end{tabular}


ada di dalamnya. Dapat disimpulkan bahwa semakin besar kandungan zat aktif dapat membunuh nyamuk semakin banyak.

Hasil penelitian ini sejalan dengan penelitian terdahulu dilakukan oleh peneliti lain bahwa semakin konsentrasi maka semakin banyak pula kematian pada hewan uji coba. Penelitian yang dilakukan oleh Syam 2015 yang meneliti ekstrak buah pare (Momordica charantia L) terhadap larva Aedes aegypti, menunjukkan bahwa semakin tinggi konsentrasi ekstrak buah pare (Momordica charantia L) yang diujikan, semakin banyak larva Aedes aegypti yang mengalami kematian. Penelitian yang dilakukan oleh Syam 2015 mengujikan 4 konsentrasi ekstrak buah pare (Momordica charantia L) terhadap larva Aedes aegypti, yaitu konsentrasi $5 \%$, $10 \%$, dan $15 \%$, menunjukkan hasil bahwa semakin tinggi konsentrasi semakin besar pula kematian larva Aedes aegypti. Hal ini karena semakin tinggi konsentrasi ekstrak, maka semakin banyak pula kandungan senyawa metabolit sekunder pada ekstrak buah pare (Momordica charantia L) yang diujikan.

Penelitian lain juga menghasilkan hasil yang relevan dengan penelitian ini. Penelitian yang dilakukan oleh Susilawati (2015) meneliti ekstrak metanol buah pare (Momordica charantia L) yang diujikan pada larva Aedes aegypti. Hasil dari penelitian tersebut yaitu kematian larva Aedes aegypti semakin tinggi seiring dengan bertambahnya konsentrasi semakin tinggi kematian larva Aedes aegypti. Penelitian Susilawati (2015) menggunakan 5 konsentrasi ekstrak metanol buah pare (Momordica charantia L) yang diujikan pada larva Aedes aegypti. Hasil yang diperoleh dari penelitian Susilawati (2015) selama 24 jam pengamatan yaitu pada konsentrasi $0,125 \mathrm{mg} / \mathrm{mL} ; 0,250 \mathrm{mg} / \mathrm{mL} ; 0,5$ $\mathrm{mg} / \mathrm{mL} ; 1,0 \mathrm{mg} / \mathrm{mL}$; dan 2 ekstrak metanol buah pare, larva Aedes aegypti mengalami kematian yang semakin banyak pada konentrasi yang semakin tinggi. Hasil tersebut menunjukkan bahwa semakin tinggi konsentrasi ekstrak metanol buah pare (Momordica charantia L) semakin tinggi pula kematian larva Aedes aegypti yang diujikan pada penelitian.

Kematian nyamuk Aedes aegypti terdapat pada semua konsentrasi ekstrak buah pare dan kontrol positif, sedangkan pada kontrol negatif tidak terdapat kematian. Hal ini membuktikan bahwa kematian nyamuk Aedes aegypti disebabkan oleh ekstrak buah pare, bukan karena faktor lingkungan (suhu, kelembaban, d11). Pengamatan pada penelitian yang dilakukan di laboratorium menunjukkan adanya kematian nyamuk Aedes aegypti.

Penyebab kematian nyamuk Aedes aegypti dikarenakan adanya kontak dengan obat nyamuk elektrik cair berinsektisida ekstrak buah pare (Momordica charantia L). Obat nyamuk dengan metode elektrik cair berdampak langsung melalui sistem pernafasan nyamuk. Alat elektrik cair berisi insektisida ekstrak buah pare (Momordica charantia L) yang dipanaskan akan mengeluarkan kandungan metabolit yang terkandung dalam ekstrak buah pare (Momordica charantia L).

Persentase (\%) kematian nyamuk Aedes aegypti pada berbagai pemberian ekstrak buah pare dapat dilihat pada gambar grafik 1 . Berdasarkan Gambar 1 yang menunjukkan grafik kematian nyamuk Aedes aegypti didapatkan bahwa terdapat kenaikan kematian nyamuk Aedes aegypti pada setiap konsentrasi ekstrak buah pare (Momordica charantia L). Kematian tertinggi terdapat pada konsentrasi $59 \%$ dengan presentase kematian nyamuk sebesar $86 \%$.

Hasil uji normalitas data menunjukkan bahwa pada konsentrasi 13\%, konsentrasi 19\%, konsentrasi 27\%, konsentrasi 40\%, dan konsentrasi $59 \%$ data terdistribusi normal kare-

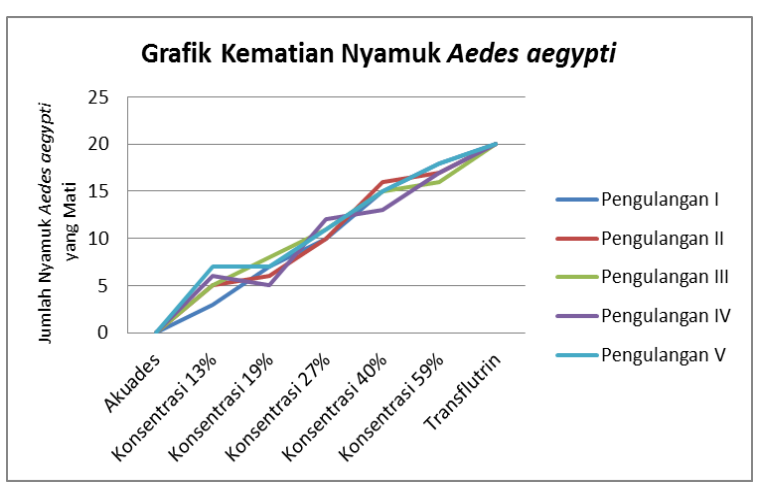

Gambar 1. Grafik Kematian Nyamuk Aedes aegypti

(Sumber: Dokumentasi pribadi) 
na memiliki nilai signifikansi $>0,05$. Sedangkan hasil uji normalitas data pada kontrol negatif (akuades) dan kontrol positif (obat nyamuk berbahan aktif transflutrin) tidak diketahui hasilnya, sehingga dapat dikatakan bahwa data tidak terdistribusi normal.

Hasil dari uji homogenitas varian yang yang dilakukan didapat nilai $\mathrm{p}=0,031$, nilai signifikansi $p<0,05$ sehingga dapat dikatan bahwa varians data kelompok yang di uji adalah tidak homogen.

Hasil dari uji Kruskal Wallis yaitu $p=0,001$, nilai $p=<0,05$ yang berarti bahwa terdapat perbedaan rata-rata kematian nyamuk Aedes aegypti pada berbagai ekstrak buah pare (Momordica charantia L). Hal ini dapat disimpulkan bahwa terdapat pengaruh setelah pemaparan ekstrak buah pare (Momordica charantia L) terhadap nyamuk Aedes aegypti. Maka dapat dilanjutkan dengan uji Post Hoc untuk mengetahui ada tidaknya perbedaan ratarata kematian antar konsentrasi.

Hasil analisis Post Hoc menunjukkan bahwa rata-rata jumlah kematian nyamuk Aedes aegypti berbeda secara signifikan. Hal ini dapat dilihat pada tabel 4. Berdasarkan hasil uji beda terdapat konsentrasi yang tidak berbeda secara signifikan yaitu pada kelompok ekstrak buah pare konsentrasi $13 \%$ dengan konsentrasi $19 \%$ dengan niali $\mathrm{p}=0,133$. Pada konsentrasi $59 \%$ memiliki nilai jumlah nilai mean yang lebih besar dari konsentrasi lainnya. Dapat dikatakan bahwa konsentrasi 59\% memilik efek yang lebih besar dibandingkan dengan konsentrasi $13 \%$, 19\%, 27\%, dan 40\%. Berdasarkan hasil uji post hoc uji mann whitney, semakin besar konsentrasi semakin tinggi efek insektisida ekstrak buah pare (Momordica charantia L) terhadap kematian nyamuk Aedes aegypti. Semakin tinggi konsentrasi, semakin banyak pula kandungan senyawa metabolit sekunder yang terdapat pada insentisida ekstrak buah pare (Momordica charantia L).

Hasil pengamatan pada penelitian menunjukkan bahwa nyamuk Aedes aegypti yang telah diberi perlakuan ekstrak buah pare (Momordica charantia $\mathrm{L}$ ) dengan metode elektrik cair akan mengalami perubahan tingkah laku, yang semula nyamuk dapat bergerak aktif namun menjadi lamban dan sulit bergerak yang

Tabel 4. Hasil uji beda rata-rata jumlah kematian nyamuk

\begin{tabular}{|c|c|c|c|}
\hline No & Konsentrasi & Konsentrasi & Significance $(p)$ \\
\hline \multirow{6}{*}{1} & \multirow{6}{*}{$13 \%$} & $19 \%$ & 0,133 \\
\hline & & $27 \%$ & 0,008 \\
\hline & & $40 \%$ & 0,008 \\
\hline & & $59 \%$ & 0,008 \\
\hline & & Akuades & 0,005 \\
\hline & & Obat nyamuk berbahan aktif transflutrin & 0,005 \\
\hline \multirow{5}{*}{2} & \multirow{5}{*}{$19 \%$} & $27 \%$ & 0,008 \\
\hline & & $40 \%$ & 0,008 \\
\hline & & $59 \%$ & 0,008 \\
\hline & & Akuades & 0,005 \\
\hline & & Obat nyamuk berbahan aktif transflutrin & 0,005 \\
\hline \multirow{4}{*}{3} & \multirow{4}{*}{$27 \%$} & $40 \%$ & 0,008 \\
\hline & & $59 \%$ & 0,008 \\
\hline & & Akuades & 0,005 \\
\hline & & Obat nyamuk berbahan aktif transflutrin & 0,005 \\
\hline \multirow[b]{3}{*}{4} & \multirow[b]{3}{*}{$40 \%$} & $59 \%$ & 0,010 \\
\hline & & Akuades & 0,005 \\
\hline & & Obat nyamuk berbahan aktif transflutrin & 0,005 \\
\hline & & Akuades & 0,005 \\
\hline 5 & $59 \%$ & Obat nyamuk berbahan aktif transflutrin & 0,005 \\
\hline 6 & Akuades & Obat nyamuk berbahan aktif transflutrin & 0,003 \\
\hline
\end{tabular}


kemudian nyamuk menjadi mati. Nyamuk dapat dikatakan knowkdown apabila nyamuk jatuh, menggelepar dalam keadaan telentang, dengan pergerakan nyamuk yang semakin lambat. Nyamuk dapat dikatakan mati apabila tidak ada pergerakan sama sekali setelah adanya pengusikan.

Kematian nyamuk Aedes aegypti dikarenakan adanya kontak dengan obat nyamuk elektrik cair ekstrak buah pare. Buah pare memiliki kandungan senyawa metabolit yang memiliki efek insektisida. Senyawa tersebut yaitu alkaloid dan flavonoid (Syam, 2015). Flavonoid merupakan kelompok senyawa fenol yang terbesar yang ditemukan di alam (Lombogia, 2016). Flavonoid merupakan senyawa yang dikelompokkan kedalam racun aksonik. Mekanisme masuknya senyawa aktif flavonoid ke dalam tubuh nyamuk Aedes aegypti melalui sistem pernafasan. Pengaruhnya sangat cepat terhadap serangga yang sedang terbang, sehingga menyebabkan cepatnya otot-otot menjadi paralysis (kelumpuhan), serta mempengaruhi sistem saraf pusat (Nindatu, 2011).

Flavonoid merupakan zat yang mengganggu respirasi dan menyebabkan penurunan fungsi oksigen yang kemudian menyebabkan segala gangguan syaraf dan gangguan pada spirakel yang berakhir pada kematian (Utami, 2016). Flavonoid memiliki potensi untuk mengganggu metabolisme energi di dalam mitokondria dengan menghambat system pengangkutan elektron. Adanya hambatan pada sistem pengangkutan elektron akan menghalangi produksi Adenosine Triphosphate ATP dan menyebabkan penurunan pemakaian oksigen oleh mitokondria, sehingga akan menghambat rantai respirasi, menghambat fosforilasi oksidatif, serta memutuskan rangkaian antara rantai respirasi dengan fosforilasi oksidatif. Hal ini menyebabkan flavonoid dapat bekerja sebagai inhibitor pernapasan pada nyamuk. Selain itu flavonoid merupakan senyawa pertahanan tumbuhan yang dapat bersifat menghambat makan serangga dan juga bersifat toksis. Flavonoid menyebabkan vasokonstriksi yang berlebihan, sehingga permeabilitas rongga badan pada nyamuk Aedes aegypti menjadi rusak dan hemolimfe tidak dapat didistribusi secara sempurna (Iftita, 2016). Kandungan lain dalam ekstrak buah pare yaitu alkaloid merupakan antikolinesterase yang berfungsi menghambat kerja enzim cholinesterase yang mempengaruhi transmisi implus syaraf (Utami, 2016).

Menurut asumsi peneliti, dalam penelitian ini jumlah kuantitatif senyawa metabolit aktif pada ekstrak buah pare (Momordica charantia L), tidak diketahui secara pasti, namun diyakini bahwa zat aktif tersebut dapat berberan penting dalam mekanisme insektisida ekstrak buah pare (Momordica charantia L). Konsentrasi yang berbeda yang digunakan pada penelitian memiliki jumlah senyawa metabolit aktif yang berbeda-beda, sehingga menyebabkan perbedaan banyak sedikitnya jumlah senyawa yang mengenai nyamuk, yang mengakibatkan perbedaan banyak sedikitnya kematian nyamuk Aedes aegypti. Berdasarkan hasil dan pembahasan di atas dapat diketahui bahwa semakin tinggi tingkat konsentrasi ekstrak buah pare (Momordica charantia L), semakin banyak pula nyamuk yang mati.

Pilihan $\mathrm{LC}_{50}$ dan $\mathrm{LC}_{90}$ dalam penelitian ini dimaksud untuk mengukur daya bunuh ekstrak buah pare (Momordica charantia L) terhadap nyamuk Aedes aegypti. Hasil uji probit menunjukkan bahwa nilai $\mathrm{LC}_{50}$ pada penelitian ini yaitu $24,41 \%$. Hal ini berarti konsentrasi yang dapat mematikan 50\% nyamuk Aedes aegypti dengan menggunakan ekstrak buah pare (Momordica charantia L) dalam waktu 24 jam adalah $24,41 \%$. Nilai $\mathrm{LC}_{90}$ pada penelitian ini yaitu $70,54 \%$. Hal ini berarti bahwa konsentrasi yang dapat mematikan $90 \%$ nyamuk Aedes aegypti dengan menggunakan ekstrak buah pare (Momordica charantia L) dalam waktu 24 jam adalah $70,54 \%$. Semakin rendah nilai $\mathrm{LC}_{50}$ dan $\mathrm{LC}_{90}$ maka semakin tinggi nilai toksisitas insektisida tersebut. Suatu ekstrak dikatakan toksik apabila nilai $\mathrm{LC}_{50}<1000 \mathrm{ppm}$ atau setara dengan $0,1 \%$. Dapat disimpulkan bahwa ekstrak buah pare memiliki toksisitas yang sangat rendah. 
Insektisida nabati dapat dikatakan memiliki kemampuan sebagai insektisida apabila dapat membunuh 10\%-90\% nyamuk, sedangkan insektisida nabati dapat dikatakan efektif apabila dapat membunuh nyamuk $80 \%$ $90 \%$ (WHO, 2016). Pada penelitian ini ekstrak buah pare dengan konsentrasi tertinggi 59\% dapat membunuh $86 \%$ nyamuk Aedes aegypti. Dapat disimpulkan bahwa ekstrak buah pare efektif sebagai insektisida terhadap nyamuk Aedes aegypti.

Insektisida nabati ekstak buah pare memiliki keunggulan yaitu apabila diaplikasikan hanya sedikit meninggalkan residu di lingkungan, selain itu residu yang tertinggal cepat ternetralisir oleh lingkungan sehingga tidak menyebabkan pencemaran lingkungan dan tidak menyebabkan resistensi terhadap nyamuk Aedes aegypti. Namun Insektisida ekstrak buah pare juga memiliki kelemahan yaitu untuk membuat ekstrak buah pare memerlukan biaya yang mahal, selain itu untuk membuat ekstrak buah pare memerlukan buah pare mentah yang cukup banyak, buah pare mentah dengan berat 1 $\mathrm{kg}$ hanya menjadi $100 \mathrm{ml}$ ekstrak. Pembuatan ekstrak buah pare juga memerlukan waktu yang cukup lama yaitu sekitar 2 minggu.

Insektisida ekstrak buah pare dapat diaplikasikan di masyarakat namun perlu dilakukan sosialisasi kepada masyarakat untuk mengenalkan insektisida ekstrak buah pare. Masyarakat dapat membeli buah pare yang tersedia di pasar, kemudian mengekstrak buah pare tersebut untuk mendapatkan senyawa aktif metabolit, setelah itu ekstrak buah pare dimasukkan kedalam alat elektrik cair. Aplikasi insektisida ekstrak buah pare termasuk sulit.

\section{PENUTUP}

Simpulan dari penelitian ini yaitu obat nyamuk elektrik cair ekstrak buah pare memiliki kemampuan sebagai insektisida terhadap nyamuk Aedes aegypti. Konsentrasi ekstrak buah pare yang paling besar pengaruhnya terhadap kematian nyamuk Aedes aegypti pada penelitian yaitu konsentrasi 59\% dengan kematian sebesar $86 \%$. Hasil uji probit menunjukkan nilai LC $_{50}$ sebesar $24,41 \%$ dan $\mathrm{LC}_{90}$ sebasar $70,54 \%$, Semakin tinggi konsentrasi ekstrak buah pare, persentase kematian nyamuk semakin besar. Hal ini dikarenakan kandungan senyawa aktif yang terdapat dalam ekstrak buah pare yaitu alkaloid dan flavonoid.

Saran yang dapat diajukan oleh peneliti yaitu apabila ingin melakukan penelitian lanjut sebaiknya menggunakan bahan dengan berat dan ukuran yang sama untuk menguapkan ekstrak, agar tidak mempengaruhi banyak sedikitnya zat yang terserap atau dapat menggunakan bahan seperti produk di pasaran yang belum terpapar insektisida kimia.

\section{DAFTAR PUSTAKA}

Astriani, Y., \& Widawati, M. 2016. Potensi Tanaman di Indonesia sebagai Larvasida Alami untuk Aedes aegypti. Jurnal Spirakel, 8(2): 37-46.

Borokini, T. I., Inghere, D.A., Clement, M., Ajiboye, T.O., \& Alowonle, A.A. 2013. Ethnobiological Survey of Traditional Medicine Practices in Oyo State. Medicinal Plants Studies, 1(5): 1-16.

Ikawati, B., Sunaryo., \& Widiastuti, D. 2015. Peta status kerentanan Aedes aegypti (Linn.) terhadap insektisida cypermethrin dan malathion di Jawa Tengah. Jurnal Aspirator, (7)1: 23-28

Iftita, F.A. 2016. Uji Efektivitas Rendaman Daun Singkong (Manihot utilissima) sebagai Insektisida terhadap Nyamuk Aedes aegypti dengan Metode Elektrik Cair. Jurnal Kesehatan Masyarakat, (4)2: 20-29.

Kementrian Kesehatan RI. 2010. Buletin Jendela Epidemiologi. Jakarta: Kementrian Kesehatan RI.

Kementrian Kesehatan RI. 2016. Profil Kesehatan Indonesia 2016. Jakarta: Kementrian Kesehatan RI.

Lombogia, B., Budiarso, F., \& Bodhi, W. 2016. Uji daya hambat ekstrak daun lidah mertua (Sansevieriae trifasciata folium) terhadap pertumbuhan bakteri Escherichia coli dan Streptococcus sp. Jurnal E-Biomedik, (4)1: 1-5.

Nihayah, E. 2014. Efektivitas Ekstrak Daun Pandan Wangi (Pandanus amaryllifolius) sebagai Obat Nyamuk Elektrik Cair terhadap Kematian Nyamuk Aedes aegypti. Skripsi. Semarang: Universitas Negeri Semarang. 
Nikmah, F., Sulistyani., \& Hestiningsih, R. 2016. Potensi Ekstrak Bunga Kluwih (Artocarpus altilis Linn) sebagai Insektisida terhadap Kematian Nyamuk Aedes aegypti Linn dengan Metode Elektrik Cair. Jurnal Kesehatan Masyarakat, (4)1: 380-389.

Nindatu, M., Tuhumury, N. L., \& Kaihena, M. 2011. Pengembangan Ekstrak Etanol Daun Lavender (Lavandula angustifolia) sebagai Antinyamuk Vektor Filariasis Culex sp. Jurnal Molucca Medica, (4)1: 19-27.

Panghiyangani, R., Marlinae, L., Yuliana., Fauzi. R., Noor, F. D., \& Anggriyani. W.P. 2012. Efek Ekstrak Rimpang Kunyit (Curcuma domestica Val.) sebagai Larvasida Aedes aegypti Vektor Penyakit Demam Dengue dan Demam Berdarah Dengue di Kota Banjarbaru. Jurnal Universitas Lambung Mangkurat, (4)1: 1-6.

Prasetyowati, H., Hendri, J., \& Wahono, T. 2016. Status Resistensi Aedes aegypti (Linn.) terhadap Organofosfat di Tiga Kotamadya DKI Jakarta. Jurnal Balaba, (12)1: 23-30

Susilawati \& Hermansyah. 2015. Aktivitas Larvasida Ekstrak Metanol Buah Pare (Momordica charantia L.) terhadap Larva Aedes aegypti. Jurnal Molekul, (10)1: 33-37.

Suwandi, J. F., \& Halomoan, J. T. 2017. Pengendalian Vektor Virus Dengue dengan
Metode Release of Insect Carrying Dominant Lethal (RIDL). Jurnal Majority, (6)1: 46-50.

Syam., Ilham., \& Pawen, E. P. 2015. Efektifitas Ekstrak Buah Pare (Momordica charana) dalam Mematikan Jentik Aedes aegypti. Jurnal Kesehatan Masyarakat Andalas. (10).1: 19-23.

Trapsilowati, W., Mardihusodo, S. J., Prabandari, Y. S., \& Mardikanto. T. 2015. Partisipasi Masyarakat dalam Pengendalian Vektor Demam Berdarah Dengue di Kota Semarang Provinsi Jawa Tengah. Jurnal Vektora, (7)1: 15-22. .

Utami, I, W., \& Cahyati, W, H. 2016. Potensi Ekstrak Daun Kamboja sebagai Insektisida terhadap Nyamuk Aedes aegypti. HIGEIA, (1)1: 22-28.

WHO. 2016. Test Procedures for Insecticide Resistance Monitoringinmalaria Vector Mosquitoes. WHO Press: Geneva, Switzerland.

Wiryadiputra, S., Rusda, I. \& Asyiah, I, N. 2014. Pengaruh Ekstrak Tanaman Picung (Pangium edule) sebagai Pestisida Nabati Terhadap Mortalitas Penggerek Buah Kopi. Jurnal Pelita Perkebunan, (30)3: 220-228.

Wulandari, Sri. 2012. Potensi Getah Buah Pepaya (Carica papaya L) terhadap Mortalitas Larva Nyamuk Aedes albopictus. Jurnal Universitas Riau Pekan Baru. (9)1 